\title{
Penerapan Model Pembelajaran Make A Match Dengan Menggunakan Media Kartu Dan Kaitannya Dengan Peningkakan Kemampuan Struktur Kalimat Passive Voice Bahasa Inggris Pada Siswa Kelas XI-IA4 SMAN 11 Banda Aceh
}

\author{
Khairani, S.Pd.i \\ SMAN 11 Banda Aceh
}

\begin{abstract}
Abstrak
Penelitian ini bertujuan untuk menjelaskan strategi pembelajaran yang diterapkan dengan menggunakan model make a match dengan media kartu. Meningkatkan pemahaman kalimat Passive voice melalui model pembelajaran make a match dengan media kartu pada siswa kelas XI SMAN 11 Banda Aceh. Meningkatkan kemampuan guru mengelola pembelajaran Bahasa Inggris melalui model pembelajaran make a match dengan media kartu. Penelitian ini dilaksanakan di SMAN 11 Banda Aceh yang beralamat di Jl. Paya Umeet. Desa Blang Cut, Kecamatan Lueng Bata, Banda Aceh. PTK ini di laksanakan dalam dua siklus yang masing-masing siklus terdiri dari 2 kali pertemuan. Subjek penelitian ini adalah siswa kelas XI-IA4 tahun pelajaran 2015-2016 semester ganjil dengan jumlah siswa 25 orang. Alat pengumpul data dalam penelitian ini yaitu lembar evaluasi berupa soal pretest dan ulangan harian, observasi, dan angket tentang tanggapan siswa. Data yang dikumpulkan dalam penelitian ini adalah data kualitatif tentang aktifitas siswa dan guru dalam mengelola pembelajaan dengan penerapan pendekatan Make a match yang diperoleh pengamatan dengan menggunakan lembar pengamatan. pembelajaran model make a match dengan menggunakan media kartu dapat meningkatkan aktivitas siswa selama pelaksanaan pembelajaran Bahas Inggris. Rata-rata aktivitas siswa pada siklus I mencapai $66 \%$ dan pada siklus II naik menjadi 85\%. Pembelajaran model make a match dengan menggunakan media kartu guru dapat meningkatkan prestasi belajar siswa yang ditandai dengan peningkatan hasil belajar siswa pada setiap siklus. Pada siklus I kemampuan siswa dalam membuat kalimat passive voice mencapai ketuntasan $40 \%$ dan pada siklus II meningkat mencapai $88 \%$ ketuntasan secara klasikal. Melalui penerapan Pembelajaran model make a match dengan menggunakan media kartu guru dapat meningkatkan kemampuannya dalam mengelola pembelajaran dan meningkat dari siklus ke siklus. Kemampuan guru mengelola pembelajaran pada siklus I mencapai rata-rata $60,71 \%$ dan pada siklus II meningkat menjadi 87, 5\%.
\end{abstract}

Kata Kunci : Model Pembelajaran, Make A Match, Media Kartu, Kalimat Passive Voice

\section{Pendahuluan}

Mata pelajaran Bahasa Inggris mempunyai karakteristik yang berbeda dengan mata pelajaran lain. Perbedaan ini terletak pada fungsi bahasa sebagai alat komunikasi. Selain diperlukan penguasaan kosa kata dan tata bahasa, juga diperlukan keterampilan dalam mengaplikasikannya dalam kegiatan komunikasi, baik lisan maupun tulisan (Depdiknas, 2006:2). Salah satu bentuk tata bahasa ( structure) Bahasa Inggris yang telah diajarkan sejak Sekolah Menengah Pertama sampai Sekolah Menengah Atas adalah bentuk kalimat Passive Voice atau biasa disebut kalimat pasif. Materi ini termasuk materi yang dianggap sulit untuk dikuasai oleh siswa karena perubahan 
bentuk kalimat Passive Voice tergantung pada setiap tenses (waktu) yang sulit dikerjakan oleh sebahagian siswa walaupun telah berulangkali diberikan penjelasan dan latihan tentang itu.

Berdasarkan hasil observasi yang telah peneliti lakukan di SMA 11 Banda Aceh, ternyata cara guru mengajar di kelas XI umumnya masih menggunakan metode ceramah. Guru masih menjelaskan dan siswa hanya mendengar dan mencatat. Artinya guru dalam mengajar cenderung bersifat informatif atau hanya transfer ilmu pengetahuan dari guru ke siswa sehingga siswa belum terlibat secara aktif dalam proses pembelajaran. Salah satu hal yang perlu diketahui bahwa setiap anak itu berbeda secara individual, maka perbedaan individual ini perlu mendapat perhatian yang lebih banyak. Belajar hanya akan terjadi dengan kegiatan anak itu sendiri. Ia bukan bejana yang harus diisi oleh guru dengan berbagai pengetahuan.

Setelah dilakukan evaluasi terhadap hasil belajar siswa ternyata dengan pendekatan pembelajaran seperti itu hasil belajar siswa dirasa belum maksimal. Hal ini tampak pada pencapaian nilai akhir siswa. Dalam satu tahun belakangan ini siswa yang memperoleh nilai $70 \mathrm{ke}$ atas tidak lebih dari $25 \%$. Untuk memperbaiki hal tersebut peneliti memutuskan untuk mengajarkan materi ini melalui suasana yang menyenangkan dengan model pembelajaran Make a match berupa permainan dengan menggunakan media pembelajaran berupa kartu. Berdasarkan paparan tersebut di atas peneliti merasa sangat urgen untuk melakukan penelitian tindakan kelas dengan judul" Penerapan model pembelajaran make a match dengan menggunakan media kartu dan kaitannya dengan peningkakan kemampuan struktur kalimat Passive Voice Bahasa Inggris pada siswa kelas XI-IA4 SMAN 11 Banda Aceh.

\section{Tujuan Penelitian}

Penelitian ini bertujuan untuk menjelaskan strategi pembelajaran yang diterapkan dengan menggunakan model make a match dengan media kartu. Meningkatkan pemahaman kalimat Passive voice melalui model pembelajaran make a match dengan media kartu pada siswa kelas XI SMAN 11 Banda Aceh. Meningkatkan kemampuan guru mengelola pembelajaran Bahasa Inggris melalui model pembelajaran make a match dengan media kartu.

\section{LANDASAN TEORITIS \\ Definisi struktur Kalimat}

Susilo (1990:2) mengemukakan lima ciri kalimat bahasa Indonesia kelima ciri tesebut ialah: bermakna, bersistem urutan frase, dapat berdiri sendiri dalam hubungannya dengan kalimat yang lain, berjeda dan berhenti dengan berakhirnya intonasi. Kelima ciri tersebut ialah ciri umum sebuah kalimat. kalimat yang memenuhi kelima ciri tersebut ialah kalimat bahasa Indonesia, namun hal itu belum menjamin bahwa kalimat itu ialah kalimat bahasa Indonesia baku.

Kalimat baku harus gramatikal, yaitu kalimat baku yang harus memenuhi kaidah yang berlaku di dalam bahasa Indonesia. Kaidah-kaidah tersebut menurut Susilo (1990:4) ialah harus memenuhi tata kalimat (sintaksis), tata frase (frasiologi), tata morfem (morfologi) dan tata fonem (fonemik, fonologi). Kalimat bahasa Indonesia secara gramatikal setidaknya terdiri atas unsur subjek dan unsur predikat. Sebuah kalimat dapat berdiri sendiri meskipun tanpa objek atau keterangan, tapi unsur subjek dan predikat tidak dapat ditinggalkan. Karena kedua unsur ini (subjek dan predikat) memiliki sifat ketergantungan. Unsur subjek tidak akan memiliki makna tanpa unsur 
predikat, begitu pula sebaliknya dengan unsur predikat takkan memiliki makna tanpa adanya unsur subjek.

\section{Kalimat passive Voice}

Dalam Bahasa Inggris terdapat 2 macam kalimat yaitu active voice (kalimat aktif) dan passive voice (kalimat pasif). Kalimat pasif adalah jenis kalimat atau klausa di mana subjek menerima tindakan dari kata kerja. Pada kalimat pasif subjek kalimat tidak melakukan suatu tindakan/aksi melainkan subjek menerima tindakan. Berbeda dengan kalimat aktif dimana subjek bertindak sebagai pelaku tindakan. Kalimat aktif dapat di ubah bentuk menjadi kalimat pasif namun hanya berlaku pada kalimat dengan transitive verbs. Transitive verbs adalah kata kerja yang diikuti direct object.

\section{Pengertian Model pembelajaran}

Seorang guru diharapkan memiliki motivasi dan semangat pembaharuan dalam proses pembelajaran yang dijalaninya. Menurut Sardiman A. M. (2004: 165), guru yang kompeten adalah guru yang mampu mengelola program belajar-mengajar. Mengelola di sini memiliki arti yang luas yang menyangkut bagaimana seorang guru mampu menguasai keterampilan dasar mengajar, seperti membuka dan menutup pelajaran, menjelaskan, menvariasi media, bertanya, memberi penguatan, dan sebagainya, juga bagaimana guru menerapkan. strategi, teori belajar dan pembelajaran, dan melaksanakan pembelajaran yang kondusif.

Pendapat serupa dikemukakan oleh Colin Marsh (1996 : 10) yang menyatakan bahwa guru harus memiliki kompetensi mengajar, memotivasi peserta didik, membuat model instruksional, mengelola kelas, berkomunikasi, merencanakan pembelajaran, dan mengevaluasi. Semua kompetensi tersebut mendukung keberhasilan guru dalam mengajar. Model pembelajaran diartikan sebagai prosedur sistematis dalam mengorganisasikan pengalaman belajar untuk mencapai tujuan belajar. Dapat juga diartikan suatu pendekatan yang digunakan dalam kegiatan pembelajaran.

\section{Definisi Model Pembelajaran Make a Match}

Model pembelajaran make a match ini merupakan pembelajaran yang dikembangkan oleh Lorna Curran pada tahun 1994. Salah satu keuntungan model ini adalah siswa mencari pasangan sambil belajar mengenai monsep atau topic dalam suasana yang menyenangkan. Model ini bisa digunakan pada semua mata pelajaran dan untuk semua tingkatan usia anak didik (Anita Lie 2003 : 33 )

\section{Media Kartu}

Media kartu merupakan suatu media yang biasa digunakan sebagai alat bantu permainan. Dalam penggunaannya, permainan ini dimainkan secara berpasangan. Pada prinsipnya permainan ini melatih siswa untuk bisa menemukan jawaban yang benar yang terdapat pada pasangannya.

Aturan main yang ditetapkan pada penggunaan media kartu ini adalah sebagai berikut :

1. Guru menyiapkan beberapa kartu yang berisi beberapa konsep atau topik yang cocok untuk sesi review, satu bagian kartu soal dan bagian lainnya kartu jawaban.

2. Setiap siswa mendapatkan sebuah kartu yang bertuliskan soal/jawaban.

3. Tiap siswa memikirkan jawaban/soal dari kartu yang dipegang. 
4. Setiap siswa mencari pasangan kartu yang cocok dengan kartunya. Misalnya: pemegang kartu yang bertuliskan kalimat aktif dan pemegang kartu lainnya kalimat pasiv

5. Setiap siswa yang dapat mencocokkan kartunya sebelum batas waktu diberi poin.

6. Jika siswa tidak dapat mencocokkan kartunya dengan kartu temannya (tidak dapat menemukan kartu soal atau kartu jawaban) akan mendapatkan hukuman, yang telah disepakati bersama.

7. Setelah satu babak, kartu dikocok lagi agar tiap siswa mendapat kartu yang berbeda dari sebelumnya, demikian seterusnya.

8. Siswa juga bisa bergabung dengan 2 atau 3 siswa lainnya yang memegang kartu yang cocok.

9. Guru bersama-sama dengan siswa membuat kesimpulan terhadap materi pelajaran.

\section{METODE PENELITIAN}

\section{Tempat dan Waktu Penelitian}

Penelitian ini dilaksanakan di SMAN 11 Banda Aceh yang beralamat di Jl. Paya Umeet. Desa Blang Cut, Kecamatan Lueng Bata, Banda Aceh. PTK ini di laksanakan dalam dua siklus yang masing-masing siklus terdiri dari 2 kali pertemuan.

\section{Subjek Penelitian}

Subjek penelitian ini adalah siswa kelas XI-IA4 tahun pelajaran 2015-2016 semester ganjil dengan jumlah siswa 25 orang.

\section{Rancangan Penelitian}

Sesuai dengan jenis penelitian yang dipilih, yaitu penelitian tindakan kelas, maka penelitian ini menggunakan model penelitian tindakan dari Kammis dan Taggart ( dalam Arikunto, Suharsimi, $2002: 83$ ), yaitu berbentuk spiral dari siklus yang satu ke siklus yang berikutnya. Setiap siklus meliputi planning ( rencana), action ( tindakan ), observation ( pengamatan) dan reflection ( refleksi ).

\section{Alat Pengumpul Data}

Alat pengumpul data dalam penelitian ini yaitu lembar evaluasi berupa soal pretest dan ulangan harian, observasi, dan angket tentang tanggapan siswa

\section{Teknik Pegolahan Data}

Data yang dikumpulkan dalam penelitian ini adalah data kualitatif tentang aktifitas siswa dan guru dalam mengelola pembelajaan dengan penerapan pendekatan Make a match yang diperoleh pengamatan dengan menggunakan lembar pengamatan.

\section{Teknik Analisi Data}

Untuk menganalisis tingkat keberhasilan atau presentase keberhasilan siswa setelah proses belajar mengajar setiap siklusnya dilakukan dengan cara memberikan evaluasi berupa soal pada setiap akhir siklus. Soal yang diberikan adalah berupa essay.

Untuk menyusun dan mengolah data yang terkumpul sehingga dapat menghasilkan suatu kesimpulan yang dapat dipertanggung jawabkan, maka digunakan analisis data kuantitatif dan pada model observasi digunakan data kuantitatif. 
Data yang telah dikumpulkan diolah dengan menggunakan Tally, lalu dihitung dengan menggunakan rumus persentase sederhana sebagai berikut: $\quad P=\frac{F}{n} \times 100 \%$

Keterangan: $\mathrm{P}=$ Persentase yang dicapai

$\mathrm{F}=$ Frekuensi

$\mathrm{N}=$ Subjek penelitian

\section{HASIL PENELITIAN DAN PEMBAHASAN \\ Analisis Hasil Penelitian}

Data penelitian diperoleh dari data observasi berupa pengamatan pengelolaan pembelajaran melalui model make a match dengan menggunakan media kartu dan pengamatan aktivitas siswa pada setiap siklus. Data ulangan untuk mengetahui peningkatan prestasi belajar siswa pada materi Passive voice setelah diterapkannya pembelajaran melalui model make a match. Pelaksanaan proses pembelajaran dimulai dengan pretes. Fungsi pretes ini antara lain untuk mengetahui kemampuan awal siswa didik untuk menyiapkan siswa dalam proses belajar mengajar. Evaluasi awal (pretes) dilakukan pada hari selasa tanggal 6 Oktober 2015. Hasil evaluasi awal dengan menggunakan alat evaluasi yag telah disusun secara kolaboratif sesame guru Bahasa Inggris terhadap siswa 25 orang siswa XI-IA4 SMA Negeri 11 Banda Aceh.

Berdasakan hasil penelitian bahwa nilai hasil evaluasi awal seluruh siswa kelas XI-IA4 masih dibawah KKM yang telah ditetapkan di sekolah yaitu $\geq 70$, dan nilai rata-rata yang diperoleh ialah 58,6\%. Hal ini berarti siswa belum tuntas belajar baik secara individu maupun klasikal. Berdasarkan hasil evaluasi tersebut dapat di tarik kesimpulan sementara bahwa penguasaan materi kalimat passive voice oleh siswa kelas XI-IA4 SMA Negeri Banda Aceh masih rendah. Oleh karena itu, perlu dicari pemecahannya sehingga siswa dapat menguasai materi tersebut dengan baik.

\section{Pelaksanaan Siklus I}

\section{a. Tahap Perencanaan}

Pada tahap ini peneliti mempersiapkan perangkat pembelajaran yang terdiri dari rencana pelaksanaan pembelajaran.1. soal kuiz dan alat-alat pengajaran yang mendukung. Selain itu juga dipersiapkan lembar observasi pengelolaan pembelajaran melalui model make a match, dan lembar observasi aktifitas siswa.

\section{b. Tahap Pelaksanaan}

Pelaksanaan kegiatan belajar mengajar untuk siklus I dilaksanakan pada hari rabu tanggal 14 oktober dan 21 oktober 2015 dikelas XI-IA4 SMAN 11 Banda Aceh dengan jumlah siswa 25 orang. Dalam hal ini penelti sebagai pengajar, sedangkan yang bertindak sebagai pengamat adalah 2 orang guru Bahasa Inggris SMAN 11 Banda Aceh. Adapun proses belajar mengajar mengacu pada rencana pelajaran yang telah dipersiapkan. Pengamatan ( observasi ) dilaksanakan bersamaan dengan pelaksanaan belajar mengajar.

Pada akhir proses belajar mengajar siswa di beri tes formatif 1 dengan tujuan untuk mengetahui tingkat keberhasilan/ pemahaman siswa terhadap materi yang dipelajari selama proses belajar mengajar. Adapun data hasil penelitian pada siklus I adalah sebagai berikut :

1. Hasil kuis siswa

Untuk melihat lebih jauh keefektifan pembelajaran model make a match dalam meningkatkan hasil belajar siswa pada pelajaran Bahasa Inggris, maka diadakan kuis I dan didapatkan data sebagai berikut ini : 
Tabel Nilai kuis 1 pelajaran Bahasa Inggris melalui pembelajaran model make a match. Rekapitulasi hasil tes siswa pada siklus I

\begin{tabular}{|c|c|c|c|c|c|}
\hline \multirow{2}{*}{ No. } & \multirow{2}{*}{ Nama Siswa } & \multirow{2}{*}{ KKM } & \multirow{2}{*}{ Nilai } & \multicolumn{2}{|c|}{ Keterangan } \\
\hline & & & & Tidak Tuntas & Tuntas \\
\hline 1. & Alyatul Meta & 70 & 74 & & $\sqrt{ }$ \\
\hline 2. & Asnura & 70 & 60 & $\sqrt{ }$ & \\
\hline 3 & Dara Fakhriah & 70 & 74 & & $\sqrt{ }$ \\
\hline 4 & Dian Ully Pratiwi & 70 & 72 & & $\sqrt{ }$ \\
\hline 5 & Dinda Laura Kavita & 70 & 60 & $\sqrt{ }$ & \\
\hline 6 & Farah Habila & 70 & 65 & $\sqrt{ }$ & \\
\hline 7 & Fathya Nazira & 70 & 60 & $\sqrt{ }$ & \\
\hline 8 & Firda Silviani & 70 & 65 & $\sqrt{ }$ & \\
\hline 9 & Juli Rahayu & 70 & 74 & & $\sqrt{ }$ \\
\hline 10 & Mahdalena & 70 & 75 & & $\sqrt{ }$ \\
\hline 11 & Namira Salsabila & 70 & 65 & $\sqrt{ }$ & \\
\hline 12 & Nisrina Rifqa & 70 & 60 & $\sqrt{ }$ & \\
\hline 13 & Novita Sari & 70 & 65 & $\sqrt{ }$ & \\
\hline 14 & Nur Aida Zh & 70 & 60 & $\sqrt{ }$ & \\
\hline 15 & Nurlisa & 70 & 65 & $\sqrt{ }$ & \\
\hline 16 & Rini Zudriadi & 70 & 65 & $\sqrt{ }$ & \\
\hline 17 & Safaul Nisa & 70 & 70 & & $\sqrt{ }$ \\
\hline 18 & Safrina & 70 & 65 & $\sqrt{ }$ & \\
\hline 19 & Siqna Alzazila & 70 & 73 & & $\sqrt{ }$ \\
\hline 20 & Syiefa Aprilia & 70 & 72 & & $\sqrt{ }$ \\
\hline 21 & Syifa Salsabila & 70 & 72 & & $\sqrt{ }$ \\
\hline 22 & Syifa Urrahmah & 70 & 60 & $\sqrt{ }$ & \\
\hline 23 & Safrina & 70 & 70 & & $\sqrt{ }$ \\
\hline 24 & Safratun Nabila & 70 & 50 & $\sqrt{ }$ & \\
\hline 25 & Ulfatun Nur & 70 & 60 & $\sqrt{ }$ & \\
\hline & Jumlah & & 1586 & 15 & 10 \\
\hline $\begin{array}{l}\text { Jun } \\
\text { Jun } \\
\text { Rat }\end{array}$ & $\begin{array}{l}\text { lah Skor Maksimal Adeal } \\
\text { lah Skor Tercapai } \\
\text { Rata Skor Tercapai }\end{array}$ & $\begin{array}{c}2500 \\
1651 \\
66 \% \\
\end{array}$ & & & \\
\hline
\end{tabular}

Table Rekapitulasi hasil tes siswa pada siklus I

\begin{tabular}{|l|l|l|}
\hline No & \multicolumn{1}{|c|}{ Uraian } & \multicolumn{1}{c|}{ Hasil pada siklus } \\
\hline 1 & Jumlah skor yang tercapai & 1651 \\
2 & Jumlah siswa yang tuntas & 15 \\
3 & Persentase ketuntasan & $40 \%$ \\
4 & Nilai rata-rata hasil tes & $66 \%$ \\
\hline
\end{tabular}

Dari table diatas dapat dijelaskan bahwa dengan menerapkan pembelajaran model make a match, diperoleh nilai rata-rata hasil belajar siswa sebesar $66 \%$ dan persentase ketuntasan yang tercapai adalah $40 \%$ atau sekitar 10 orang siswa dari 25 orang siswa yang tuntas dalam pembelajaran siklus I. Hasil ini menunjukkan bahwa pada siklus pertama KKM nilai siswa belum tercapai karena siswa yang memperoleh nilai $\geq 70$ hanya sebesar $40 \%$. Hasil ini jauh di bawah persentase indicator yang telah ditetapkan yaitu sebesar $80 \%$ siswa tuntas belajar. 


\section{c. Tahap Pengamatan}

Selama proses belajar mengajar berlangsung, pengamat melakukan pengamatan terhadap pengelolaan pembelajaran dan aktivitas guru dan siswa

1. Data hasil pengamatan terhadap kemampuan guru mengelola pembelajaran

Data hasil pengamatan terhadap kemampuan guru mengelola pembelajaran selama pelaksanaan siklus I dapat dilihat dari table berikut :

Tabel Pengelolaan pembelajaran Bahasa Inggris melalui Pembelajaran model make a match

\begin{tabular}{|c|c|c|c|c|}
\hline \multirow[t]{2}{*}{ No } & \multirow[t]{2}{*}{ Aspek yang diamati } & \multicolumn{2}{|c|}{ Penilain } & \multirow{2}{*}{$\begin{array}{l}\text { Rata- } \\
\text { rata }\end{array}$} \\
\hline & & P1 & $\mathrm{P} 2$ & \\
\hline 1 & $\begin{array}{l}\text { Pengamatan KBM } \\
\text { A. Pendahuluan } \\
\text { 1. Memotivasi siswa } \\
\text { 2. Menyampaikan tujuan pembelajaran } \\
\text { 3. Menghubungkan dengan pelajaran sebelumnya } \\
\text { 4. Mengatur siswa dalam mencari pasangan }\end{array}$ & $\begin{array}{l}2 \\
2 \\
3 \\
2\end{array}$ & $\begin{array}{l}3 \\
3 \\
2 \\
2\end{array}$ & $\begin{array}{l}2,5 \\
2.5 \\
2.5 \\
2\end{array}$ \\
\hline 2 & $\begin{array}{l}\text { B. Kegiatan inti } \\
\text { 1. Mempresentasikan langkah-langkah model } \\
\text { pembelajaran make a match } \\
\text { 2. Membimbing siswa melakukan kegiatan } \\
\text { 3. Melatih keterampilan pair work } \\
\text { 4. Mengawasi setiap pasangan secara bergiliran } \\
\text { 5. Memberikan bantuan kepada pasangan yang } \\
\text { mengalami kesulitan }\end{array}$ & $\begin{array}{l}3 \\
3 \\
2 \\
2 \\
2\end{array}$ & $\begin{array}{l}2 \\
2 \\
2 \\
3 \\
3\end{array}$ & $\begin{array}{l}2.5 \\
2.5 \\
2 \\
2.5 \\
2.5\end{array}$ \\
\hline 3 & $\begin{array}{l}\text { C. Penutup } \\
\text { 1. Membimbing siswa membuat rangkuman } \\
\text { 2. Memberikan evaluasi }\end{array}$ & $\begin{array}{l}3 \\
2 \\
\end{array}$ & $\begin{array}{l}2 \\
3 \\
\end{array}$ & $\begin{array}{l}2.5 \\
2.5\end{array}$ \\
\hline & Pengelolaan waktu & 3 & 2 & 2.5 \\
\hline & $\begin{array}{l}\text { Antusiasme kelas } \\
\text { 1. Siswa antusias } \\
\text { 2. Guru antusias }\end{array}$ & $\begin{array}{l}2 \\
3\end{array}$ & $\begin{array}{l}3 \\
2\end{array}$ & $\begin{array}{l}2.5 \\
2.5\end{array}$ \\
\hline & Jumlah skor perolehan & 34 & 34 & 34 \\
\hline & Jumlah skor maksimal & 56 & 56 & 56 \\
\hline & Persentase (\%) & & & 60,71 \\
\hline
\end{tabular}

Keterangan : Nilai criteria
1) Tidak baik
2) Kurang baik
3) Cukup baik
4) Baik

Berdasarkan tabel diatas aspek-aspek yang mendapatkan criteria kurang baik adalah memotivasi siswa, mengatur siswa secara berpasangan, pengelolaan waktu. Persentase rata-rata kemampuan guru mengelola pembelajaran adalah $60,71 \%$. Antusiasme siswa juga masih kurang baik selama proses pembelajaran siklus I berlangsung. Aspek-sapek selain yang telah disebutkan tadi seperti mempresentasikan langkah-langkah pembelajaran, membimbing siswa dalam kerja pair work, melatih siswa dengan kegiatan pair work, mengawasi siswa bekerja dan memberikan bantuan kepada siswa sudah dilaksanakan dengan baik sehingga mendapat nilai cukup baik dari pengamat.

2. Data Aktivitas siswa selama pembelajaran 
Selain pengamatan terhadap kemampuan guru mengelola pembelajaran melalui pembelajaran model make a match pengamat juga melakukan pengamatan terhadap aktivitas siswa selama pembelajaran berlangsung.

Pengamatan pengamat juga ditujukan pada aktivitas siswa dan data tentang aktivitas siswa dapat dilihat dari table berikut :

Table data aktivitas siswa selama pembelajaran

\begin{tabular}{|l|l|l|l|}
\hline No & \multicolumn{1}{|c|}{ Aspek yang diamati } & $\begin{array}{c}\text { Jumlah } \\
\text { siswa aktif }\end{array}$ & Persentase \\
\hline 1 & Memperhatikan penjelasan guru & 6 & 24 \\
\hline 2 & Bekerja dalam pair work & 5 & 20 \\
\hline 3 & Mengajukan pertanyaan & 4 & 16 \\
\hline 4 & Menjawab pertanyaan & 2 & 8 \\
\hline 5 & Memperbaiki jawaban yang salah & 2 & 8 \\
\hline 6 & Mempresentasikan hasil kalimat & 2 & 8 \\
\hline 7 & Ikut merangkum materi pelajaran & 4 & 16 \\
\hline \multicolumn{2}{|c|}{ Persentase rata-rata aktivitas siswa (\%) } & 100 \\
\hline
\end{tabular}

Berdasarkan tabel di atas tampak bahwa aktivitas siswa yang paling dominan dilakukan siswa adalah memperhatikan penjelasan guru sedangkan yang kurang dominan adalah mengajukan pertanyaan, menjawab pertanyaan dan memperbaiki jawaban yang salah. Berdasarkan paparan di atas dapat dikatakan bahwa pada siklus I, secara garis besar kegiatan belajar mengajar dengan pembelajaran model make a match masih kurang maksimal dilaksanakan oleh siswa karena model pembelajaran ini baru pertama kali dipakai oleh guru dalam mengajar.

\section{d. Refleksi}

Pada siklus I secara garis besar kegiatan belajar mengajar dengan pembelajaran dengan melalui model make a match belum terlaksana dengan baik. Adapun aspek yang masih perlu ditingkatkan :

1. Guru kurang maksimal dalam memotivasi siswa dan dalam menyampaikan tujuan pembelajaran.

2. Guru kurang maksimal dalam pembagian pasangan

3. Guru kurang maksimal dalam pengelolaan waktu

4. Siswa kurang aktif dalam mengajukan pertanyaan

5. Siswa kurang aktif dalam menjawab pertanyaan

6. Siswa kurang aktif dalam memperbaiki jawaban salah

Berdasarkan hasil analisis data pada siklus I dapat disampaikan beberapa kesimpulan sebagai refleksi terhadap ketercapaian indicator siklus I yaitu:

1. Kemampuan siswa dalam memahami membuat kalimat passive voice belum mencapai indicator yang ditetapkan karena jumlah siswa yang mencapai nilai KKM $40 \%$ belum mencapai $80 \%$.

2. Kemampuan guru mengelola pembelajaran Bahasa Inggris melalui pembelajaran model make a match dengan menggunakan media kartu belum mencapai indicator karena belum rata-rata persentasenya masih berada dibawah katagori baik atau belum mencapai rentang nilai (70\%-86\%)

3. Aktivitas siswa dalam melakukan kegiatan pembelajaran belum mencapai indicator yang ditetapkan karena rata-rata persentasenya masih berada dibawah rentang nilai $(70 \%-86 \%)$ 
Berdasarkan hasil refleksi diatas dapat disimpulkan bahwa penelitian ini belum berhasil dan harus dilanjutkan ke siklus berikutnya dengan beberapa perbaikan sebagaimana dipaparkan pada tahap revisi di bawah ini.

Pelaksanaan kegiatan belajar mengajar pada siklus I ini masih terdapat kekurangan, sehingga perlu adanya revisi untuk dilakukan pada siklus berikutnya.

1. Guru perlu lebih terampil dalam memotivasi siswa dan lebih jelas dalam menyampaikan tujuan pembelajaran di mana siswa diajak untuk terlibat langsung dalam setiap kegiatan yang akan dilakukan.

2. Guru harus mengarahkan siswa untuk memperbaiki jawaban yang salah

3. Guru harus membantu mengarahkan siswa dalam mengajukan pertanyaan.

4. Guru harus memberikan dorongan dan apresiasi agar siswa lebih maksimal dalam menanggapi pertanyaan/ide selama pembelajaran berlangsung dan siswa menjadi lebih antusias dalam menyelesaikan tugas.

5. Guru harus lebih maksimal dalam pembagian pasangan.

6. Guru perlu mendistribusikan waktu secara baik dengan menambahkan informasi-informasi yang dirasa perlu dan memberi catatan.

\section{Pelaksanaan Siklus II}

\section{a. Tahap Perencanaan}

Berdasarkan hasil revisi siklus I, peneliti dan rekan pengamat melakukan beberapa perbaikan untuk siklus II dengan membuat perencanaan ulang dengan perbaikan pada beberapa aspek. Pada tahap ini peneliti memberikan soal tes formatif 2 . Selain itu juga dipersiapkan lembar observasi pengelolaan pembelajaran melalui model make a match dengan menggunakan media kartu.

\section{b. Tahap Pelaksanaan}

Pelaksanaan kegiatan belajar mengajar untuk siklus II dilaksanakan pada hari rabu tanggal 28 oktober 2015 dan selasa 4 November 2015 di kelas XI-IA4 SMAN 11 Banda Aceh dengan jumlah siswa 25 orang. Dalam hal ini peneliti bertindak sebagai pengajar yang bertindak sebagai pengamat adalah tetap pengamat yang sama seperti pada siklus I yaitu 2 orang guru SMAN 11 Banda Aceh. Adapun proses belajar mengajar mengaju pada rencana pelaksanaan pembelajaran dengan memperhatikan revisi pada siklus I, sehingga kesalahan atau kekurangan pada siklus I tidak terulang lagi pada siklus II. Pengamatan (observasi) dilaksanakan bersamaan dengan pelaksanaan belajar mengajar.

Pada akhir proses belajar mengajar siswa diberi kuiz II dengan tujuan mengetahui tingkat keberhasilan siswa dalam proses belajar mengajar yang telah dilakukan. Instrumen yang digunakan adalah tes formatif II. Data hasil penelitian pada siklus II adalah sebagai berikut.

Tabel Nilai kuis I1 pelajaran Bahasa Inggris melalui pembelajaran model make a match dengan menggunakan media kartu

\begin{tabular}{|l|l|c|c|c|c|}
\hline \multirow{2}{*}{ No. } & \multicolumn{1}{|c|}{ Nama Siswa } & \multirow{2}{*}{ KKM } & \multirow{2}{*}{ Nilai } & \multicolumn{2}{c|}{ Keterangan } \\
\cline { 5 - 6 } & & & & Tidak Tuntas & Tuntas \\
\hline 1. & Alyatul Meta & 70 & 90 & & $\sqrt{ }$ \\
\hline 2. & Asnura & 70 & 85 & & $\sqrt{ }$ \\
\hline 3 & Dara Fakhriah & 70 & 80 & & $\sqrt{ }$ \\
\hline 4 & Dian Ully Pratiwi & 70 & 90 & & $\sqrt{ }$ \\
\hline 5 & Dinda Laura Kavita & 70 & 65 & $\sqrt{ }$ & \\
\hline 6 & Farah Habila & 70 & 90 & & $\sqrt{ }$ \\
\hline
\end{tabular}




\begin{tabular}{|l|l|c|c|c|c|}
\hline 7 & Fathya Nazira & 70 & 85 & & $\sqrt{ }$ \\
\hline 8 & Firda Silviani & 70 & 90 & & $\sqrt{ }$ \\
\hline 9 & Juli Rahayu & 70 & 85 & & $\sqrt{ }$ \\
\hline 10 & Mahdalena & 70 & 85 & & $\sqrt{ }$ \\
\hline 11 & Namira Salsabila & 70 & 95 & & $\sqrt{ }$ \\
\hline 12 & Nisrina Rifqa & 70 & 95 & & $\sqrt{ }$ \\
\hline 13 & Novita Sari & 70 & 80 & & $\sqrt{ }$ \\
\hline 14 & Nur Aida Zh & 70 & 85 & & $\sqrt{ }$ \\
\hline 15 & Nurlisa & 70 & 90 & & $\sqrt{ }$ \\
\hline 16 & Rini Zudriadi & 70 & 85 & & \\
\hline 17 & Safaul Nisa & 70 & 80 & & $\sqrt{ }$ \\
\hline 18 & Safrina & 70 & 65 & & $\sqrt{ }$ \\
\hline 19 & Siqna Alzazila & 70 & 90 & & $\sqrt{ }$ \\
\hline 20 & Syiefa Aprilia & 70 & 85 & & $\sqrt{ }$ \\
\hline 21 & Syifa Salsabila & 70 & 90 & & $\sqrt{ }$ \\
\hline 22 & Syifa Urrahmah & 70 & 85 & & $\mathbf{2 0}$ \\
\hline 23 & Safrina & 70 & 90 & & \\
\hline 24 & Safratun Nabila & 70 & 65 & & \\
\hline 25 & Ulfatun Nur & 70 & 90 & & \\
\hline \multicolumn{2}{|l|}{ Jumlah } & $\mathbf{2 5 0 0}$ & $\mathbf{2 0 3 5}$ & $\mathbf{3}$ & \\
\hline $\begin{array}{l}\text { Jumlah Skor Maksimal Adeal } \\
\text { Jumlah Skor Tercapai } \\
\text { Rata Rata Skor Tercapai }\end{array}$ & $\mathbf{2 1 1 5}$ & & & \\
\hline
\end{tabular}

Table Rekapitulasi hasil tes siswa pada siklus II

\begin{tabular}{|l|l|l|}
\hline No & \multicolumn{1}{|c|}{ Uraian } & \multicolumn{1}{c|}{ Hasil pada siklus } \\
\hline 1 & Jumlah skor yang tercapai & 2115 \\
2 & Jumlah siswa yang tuntas & 22 \\
3 & Persentase ketuntasan & $88 \%$ \\
4 & Nilai rata-rata hasil tes & $85 \%$ \\
\hline
\end{tabular}

Dari table di atas dapat dijelaskan bahwa dengan menerapkan pembelajaran model make a match dengan menggunakan media kartu diperoleh nilai rata-rata hasil belajar siswa sebesar $85 \%$ dan persentase ketuntasan yang tercapai adalah $88 \%$ atau 22 dari 25 orang siswa tuntas dalam pembelajaran siklus II. Hasil ini menunjukkan bahwa pada siklus II indicator keberhasilan telah tercapai karena siswa yang memperoleh nilai $\geq 78$ telah mencapai $80 \%$ berarti telah berada diatas persentase yang ditetapkan dalam indicator.

\section{c. Tahap Pengamatan}

Selama proses belajar mengajar berlangsung, pengamat melakukan pengamatan terhadap pengelolaan pembelajaran dan aktivitas guru dan siswa

1. Kemampuan guru mengelola pembelajaran

Tabel Pengelolaan pembelajaran Bahasa Inggris melalui Pembelajaran model make a match dengan menggunakan media kartu Siklus II

\begin{tabular}{|l|l|c|c|c|}
\hline No & \multicolumn{1}{|c|}{ Aspek yang diamati } & \multicolumn{2}{c|}{ Penilain } & \multicolumn{1}{|c|}{$\begin{array}{c}\text { Rata- } \\
\text { rata }\end{array}$} \\
\cline { 3 - 5 } & \multicolumn{1}{|c|}{$\begin{array}{l}\text { Pengamatan KBM } \\
\text { a.Pendahuluan }\end{array}$} & & & \\
\hline
\end{tabular}




\begin{tabular}{|c|c|c|c|c|}
\hline & $\begin{array}{l}\text { b. Memotivasi siswa } \\
\text { c. Menyampaikan tujuan pembelajaran } \\
\text { d. Menghubungkan dengan pelajaran sebelumnya } \\
\text { e. Mengatur siswa dalam kelompok-kelompok }\end{array}$ & $\begin{array}{l}4 \\
3 \\
4 \\
3\end{array}$ & $\begin{array}{l}3 \\
4 \\
3 \\
4\end{array}$ & $\begin{array}{l}3,5 \\
3,5 \\
3,5 \\
3,5\end{array}$ \\
\hline 2 & $\begin{array}{l}\text { b.Kegiatan inti } \\
\text { a. Mempresentasikan langkah-langkah model } \\
\text { make a match } \\
\text { b. Membimbing siswa melakukan kegiatan } \\
\text { c. Melatih keterampilan pair work } \\
\text { d. Mengawasi setiap pasangan secara bergiliran } \\
\text { e. Memberikan bantuan kepada pasangan yang } \\
\text { mengalami kesulitan }\end{array}$ & $\begin{array}{l}3 \\
4 \\
3\end{array}$ & $\begin{array}{l}4 \\
3 \\
4 \\
3 \\
4\end{array}$ & $\begin{array}{l}3,5 \\
3,5 \\
3,5 \\
3 \\
3,5 \\
\end{array}$ \\
\hline 3 & $\begin{array}{l}\text { c.Penutup } \\
\text { a. Membimbing siswa membuat rangkuman } \\
\text { b.Memberikana evaluasi } \\
\text { d.Pengelolaan waktu }\end{array}$ & $\begin{array}{l}3 \\
4 \\
3\end{array}$ & $\begin{array}{l}4 \\
3 \\
4\end{array}$ & $\begin{array}{l}3,5 \\
3,5 \\
3,5\end{array}$ \\
\hline & $\begin{array}{l}\text { Antusiasme kelas } \\
\text { a. Siswa antusias } \\
\text { b. Guru antusias }\end{array}$ & $\begin{array}{l}4 \\
4 \\
\end{array}$ & $\begin{array}{l}3 \\
4 \\
\end{array}$ & $\begin{array}{l}3.5 \\
4\end{array}$ \\
\hline & Jumlah skor perolehan & 50 & 53 & 49 \\
\hline & Jumlah skor maksimal & 56 & 56 & 56 \\
\hline & Persentase $(\%)$ & & & 87,5 \\
\hline
\end{tabular}

Keterangan : Nilai criteria

1. Tidak baik

2. Kurang baik

3. Cukup baik

4. Baik

Dari table diatas tampak aspek-aspek yang diamati pada kegiatan belajar mengajar siklus II yang dilaksanakan oleh guru dengan menerapkan pembelajaran model make a match dengan menggunakan media kartu mendapat penilaian yang meningkat dari pengamat, rata-rata persentase nya mencapai $87,5 \%$. Sebagian besar aspek meningkat persentasenya dibandingkan siklus I. Aktivitas yang paling dominan dilakukan guru adalah menyampaikan tujuan pembelajaran, mempresentasikan langkah-langkah pembelajaran. Antusiasme siswa dan guru juga meningkat dibandingkan siklus I.

2. Hasil observasi aktivitas siswa

Hasil observasi berikutnya adalah aktivitas siswa yang disajikan pada table berikut :

Tabel data aktivitas siswa pada pembelajaran Bahasa Inggris sikles II.

\begin{tabular}{|l|l|l|l|}
\hline No & Aspek yang diamati & $\begin{array}{l}\text { Jumlah } \\
\text { siswa aktif }\end{array}$ & Persentase \\
\hline 1 & Memperhatikan penjelasan guru & 5 & $20 \%$ \\
\hline 2 & Bekerja dalam pair work & 4 & $16 \%$ \\
\hline 3 & Mengajukan pertanyaan & 4 & $16 \%$ \\
\hline 4 & Menjawab pertanyaan & 3 & $12 \%$ \\
\hline 5 & Memperbaiki jawaban yang salah & 3 & $12 \%$ \\
\hline 6 & Mempresentasikan hasil membuat kalimat & 4 & $16 \%$ \\
\hline 7 & Ikut merangkum materi pelajaran & 2 & $8 \%$ \\
\hline \multicolumn{2}{|c|}{ Persentase rata-rata aktivitas siswa (\%) } & $100 \%$ \\
\hline
\end{tabular}


Data hasil observasi terhadap aktivitas siswa terjadi peningkatan di siklus II. Kenaikan persentase aktivitas siswa disebabkan adanya peningkatan beberapa aspek aktivitas siswa pada siklus II. Aspek yang paling dominan dilakukan siswa adalah dengan memperhatikan penjelasan guru, diikuti mengajukan pertanyaan dan bekerja dalam pair work, mempersentasikan hasil membuat kalimat. Aspek yang kurang dominan dilakukan adalah ikut merangkum materi pelajaran.

\section{c. Refleksi}

Berdasarkan hasil pengamatan selama berlangsungnya proses pembelajaran Bahasa inggris melalui pembelajaran model make a match dengan menggunakan media kartu dapat digambarkan beberapa hal sebagai berikut :

1. Nilai siswa pada materi passive voice Bahasa Inggris mencapai nilai rata-rata $85 \%$ dengan persentase ketuntasan sebesar $88 \%$. Persentase ini telah melebihi indicator yang ditetapkan oleh peneliti untuk penelitian ini. Guru sudah meningkatkan kemampuannya mengelola pembelajaran pada siklus II walaupun ada beberapa aspek yang kurang maksimal dilaksanakan namun persentase ratarata pengelolaan pembelajaran telah mencapai indicator yang ditetapkan karena persentase nya telah mencapai $87,5 \%$ dimana berada di atas indicator yang ditetapkan.

2. Aktivitas siswa mengalami peningkatan dibandingkan siklus I. Data hasil observasi terhadap aktivitas siswa terjadi peningkatan di siklus II. Kenaikan persentase aktivitas siswa disebabkan adanya peningkatan beberapa aspek aktivitas siswa pada siklus II. Aspek yang paling dominan dilakukan siswa adalah dengan memperhatikan penjelasan guru, diikuti mengajukan pertanyaan dan bekerja dalam pair work, mempersentasikan hasil membuat kalimat. Aspek yang kurang dominan dilakukan adalah ikut merangkum materi. Oleh karena itu penelitian ini dianggap berhasil dan dapat dihentikan sampai siklus II ini.

\section{d. Revisi}

Berdasarkan hasil analisis data terhadap ketiga aspek yang ditetapkan pada indicator keberhasilan yaitu hasil belajar siswa, kemampuan guru mengelola pembelajaran dan aktivitas siswa dalam mengikuti pembelajaran Bahasa Inggris melalui pembelajaran model make a match dengan menggunakan media kartu dapat disimpulkan bahwa penelitian ini berhasil dan tidak dibutuhkan revisi lebih lanjut.

\section{Tanggapan Siswa Terhadap Penerapan Model Pembelajaran Make a Match Dengan Menggunakan Kartu.}

Setelah melakukan evaluasi dan memperoleh hasil yang memuaskan maka guru membagikan angket pada siswa untuk mengetahui tanggapan siswa terhadap penerapan model pembelajaran match a match dengan menggunakan kartu. Maka tanggapan siswa berdasarkan angket yang dibagikan dapat dilihat pada table berikut

Tabel Tanggapan Siswa Terhadap Penerapan Model Pembelajaran Match a Match Dengan Menggunakan Kartu

\begin{tabular}{|l|l|l|l|}
\hline No & \multicolumn{1}{|c|}{ Pertanyaan } & \multicolumn{1}{|c|}{ Pilihan } & Jawaban \\
\cline { 3 - 4 } & \multicolumn{1}{|c|}{ ya } & \multicolumn{1}{|c|}{ tidak } \\
\hline 1 & $\begin{array}{l}\text { Apakah kamu menyukai cara guru mengajar/menyampaikan } \\
\text { materi passive voice? }\end{array}$ & 92,93 & 5,06 \\
\hline 2 & $\begin{array}{l}\text { Apakah kamu merasa senang dengan suasana pembelajaran } \\
\text { di kelas ? }\end{array}$ & 87,87 & 7,75 \\
\hline 3 & Apakah dengan menggunakan model pembelajaran make a & 100,00 & 0,00 \\
\hline
\end{tabular}




\begin{tabular}{|l|l|l|l|}
\hline & $\begin{array}{l}\text { match dengan menggunakan kartu merasa lebih efektif saat } \\
\text { belajar? }\end{array}$ & & \\
\hline 4 & $\begin{array}{l}\text { Apakah cara guru menyampaikan materi dengan } \\
\text { menggunakan model pembelajaran make a match dengan } \\
\text { menggunakan kartu membantu kamu dalam memahami } \\
\text { materi kalimat passive voice }\end{array}$ & 91,90 & 8,09 \\
\hline 5 & $\begin{array}{l}\text { APakah dengan menerapkan model pembelajaran make a } \\
\text { match dengan menggunakan kartu dapat mempemudah } \\
\text { kamu berinteraksi dengan teman-teman? }\end{array}$ & $\begin{array}{l}85,84 \\
\text { match dengan menggunakan kartu ini meningkatkan kamu } \\
\text { dalam mempelajari materi kalimat passive voice? }\end{array}$ & 14,15 \\
\hline 7 & $\begin{array}{l}\text { Apakah kamu menyukai pendekatan dengan menerapkan } \\
\text { model pembelajaran make a match dengan menggunakan } \\
\text { kartu? }\end{array}$ & $\begin{array}{l}100,00 \\
\text { Apakah dengan menerapkan model pembelajaran make a } \\
\text { match dengan menggunakan kartu efektif digunakan untuk } \\
\text { penyampaian materi kalimat passive voice? }\end{array}$ & 91,90 \\
\hline 9 & $\begin{array}{l}\text { Apakah kamu berminat untuk mengikuti pelajaran } \\
\text { selanjutnya seperti kegiatan belajar yag telah kamu ikuti } \\
\text { pada materi kalimat passive voice? }\end{array}$ & 85,84 \\
\hline
\end{tabular}

Berdasarkan angket yang dibagikan pada siswa terhadap penerapan model pembelajaran make a match dengan menggunakan kartu pada pembelajaran materi Passive voice, dapt diketahui bahwa sekitar 92,24\% siswa menanggapi positif dan merasa senang mengikuti kegiatan pembelajaran menggunakan dengan model pembelajaran make a match dengan menggunakan kartu. Hal ini disebabkan pembelajaran dengan menerapkan model make a match dengan menggunakan kartu merupakan suatu hal yang baru bagi siswa, sehingga siswa bersemangat dalam belajar. Dalam kegiatan pembelajaran siswa dapat lebih mudah berinteraksi dengan temanteman dan siswa dapat belajar sambil bermain.

\section{Kesimpulan}

Berdasarkan hasil penelitian yang telah dipaparkan dalam dua siklus, hasil seluruh pembahasan serta analisis yang telah dilakukan dapat disimpulkan yaitu pembelajaran model make a match dengan menggunakan media kartu dapat meningkatkan aktivitas siswa selama pelaksanaan pembelajaran Bahas Inggris. Ratarata aktivitas siswa pada siklus I mencapai $66 \%$ dan pada siklus II naik menjadi $85 \%$. Pembelajaran model make a match dengan menggunakan media kartu guru dapat meningkatkan prestasi belajar siswa yang ditandai dengan peningkatan hasil belajar siswa pada setiap siklus. Pada siklus I kemampuan siswa dalam membuat kalimat passive voice mencapai ketuntasan $40 \%$ dan pada siklus II meningkat mencapai $88 \%$ ketuntasan secara klasikal. Melalui penerapan Pembelajaran model make a match dengan menggunakan media kartu guru dapat meningkatkan kemampuannya dalam mengelola pembelajaran dan meningkat dari siklus ke siklus. Kemampuan guru mengelola pembelajaran pada siklus I mencapai rata-rata $60,71 \%$ dan pada siklus II meningkat menjadi $87,5 \%$. 


\section{DAFTAR PUSTAKA}

Anita Lie. 2003. Cooperatif Learning: Mempraktekkan Cooperatif Learning di. RuangRuang Kelas. Jakarta: Gramedia

Arief S Sardiman. Et al 2003. Media Pendidikan, Pengertian, Pengembangan dan Pemanfaatannya. Jakarta: PT Raja Grafindo Persada.

Arikunto, Suharsimi. 2002. Prosedur Penelitian, Suatu Pendekatan Praktek. Jakarta: PT Rineka Cipta

Colin Marsh. (1996). Handbook for beginning teachers. Sydney : Addison. Wesley Longman Australia Pry Limited. Direktorat PAUD. (2002)

Susilo, (1990) Manajemen Sumber Daya Aparatur, BPFE, Yogyakarta 